La Sakka

\title{
NILAI LOKAL JOU SE NGOFANGARE SEBAGAI BASIS KERUKUNAN MAS YARAKAT TERNATE, MALUKU UTARA
}

\author{
Oleh: La Sakka
}

\begin{abstract}
This research was conducted in Ternate, North Maluku. This research aims to describe the local value jou se ngofangare as basic on social construction in Ternate society. This uses qualitative method, where data was collected by depth interview. Then, data was analyzed by descriptive qualitative.

This research indicates that this jou se ngofangare consists several principles are: adat se torang (regulation of social relation), galib se lakudi (power distribution), sere se duniru (regulation of God), cing se cingare (God supervision), bobaso se rasai (care to other man suffering), cara se ngale (God way), loa se banar (right act), and bari (working together). This local value is very important in maintaining the social relation among Ternate people that very plurals.
\end{abstract}

Key words: Jou se ngofangare, local value, social harmony.

\section{Pendahuluan.}

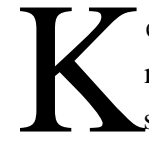

eanekaragaman budaya, etnik, dan agama yang ada di Indonesia menjadikan negara kita mau tidak mau harus menerima pluralisme mendorong terciptanya perubahan pola pikir atau perspektif, dari perspektif monokultur ke perspektif multikultur. Perubahan cara berpikir ini sangat penting untuk mencegah klaim kebenaran atau monopoli kebenaran dari satu bentuk kebudayaan tertentu yang bisa menimbulkan konflik sosial. Pada dasarnya semua 
kebudayaan (besar atau kecil) penting, karenanya tidak boleh ada semacam klaim kebudayaan yang disandarkan pada standar tertentu sebagai rasionalisasi dari kebudayaan yang lain,

Pluralisme mengandaikan semua kebudayaan dapat hidup secara berdampingan dengan damai tanpa adanya penonjolan dari satu kebudayaan tertentu. Di Indonesia, budaya tuan rumah biasanya dianggap lebih baik dan rasional dibanding kebudayaan para pendatang. Atau kebudayaan yang memiliki sejaiah yang gemilang pada masa lampau dianggap lebih baik dan lebih adilihung ketimbang budaya yang konteks sejarahnya kabur. Hal ini tentu saja memiliki potensi konflik. Ini karena semua kebudayaan memiliki kemauan untuk hidup dan menjadi landasan nilai minimal bagi masyarakat pendukungnya sendiri.

Nilai-nilai lokal yang dianut oleh masyarakat tertentu, dengan demikian tidak bisa diarahkan kepada kepentingan eksistensial-pragmatis. Atau diarahkan hanya untuk kepentingan kelompok tertentu dan kemudian mematikan eksistensi kelompok lain. Nilai-nilai lokal seperti nilaijou se ngofangare justeru seharusnya menjadi landasan nilai bagi terbentuknya masyarakat yang pluralis. Nilai-nilai lokal yang biasanya memiliki sisi moralitas yang tinggi tentu saja menjadi modal sosial yang sangat baik dalam penyusunan pola relasi antar warga pada masyarakat yang multikultur dan pada gilirannya menjadi pondasi utama bagi terbentuknya masyarakat Indonesia yang berwarna-warni.

\section{Metode Penelitian}

Penelitian ini menggunakan pendekatan kualitatif-deskriptif. Lokasi penelitian adalah Kota Ternate. Secara teknis, Kota Ternate merupakan salah satu wilayah kerja Balai Litbang Agama dan secara subtantif, Kota Ternate merupakan kota yang memiliki sejarah keagamaan yang kuat, dengan demikian diasumsikan bahwa masyarakat Ternate pasti memiliki warisan nilai-nilai lokal dari leluhur mereka sebagai modal sosial untuk merekonstruksi sistem kehidupan.

Penentuan informan yang terdiri para tokoh agama, tokoh adat, pemerintah dan masyarakat umum dilakukan secara purposive dengan menetapkan beberapa kriteria yang dianggap memenuhi persyaratan untuk melakukan wawancara. Data yang diinginkan dari para narasumber atau informan adalah pendapat mereka terhdap nilai-nilai lokal yang masih dianut oleh masyarakat Ternate sebagai modal untuk membangun kerukunan hidup antar umat beragama dan antar suku.

Pengolahan dan analisis data dilakukan dengan menelaah seluruh data yang tersedia dari berbagai sumber, yaitu hasil wawancara, catatan lapangan, dokumen- 
dokumen, gambar, foto dan lain-lain. Kemudian mereduksi data, selanjutnya menyusun ke dalam satuan-satuan, lalu dikategorisasi. Dan lalu kemudian disusun dalam bentuk tulisan deskriptif.

\section{TEMUAN DAN PEMBAHASAN}

\section{A. Deskripsi Nilai}

Masyarakat Ternate sebagai pemangku sebuah kebudayaan diasumsikan tidak hanya menciptakan budaya material yang dapat ditangkap lewat indera, dipakai, dimakan, dan diminum. Namun mereka juga menciptakan bahkan dibentuk kebudayaan yang sifatnya non-material yang acapkali menjadi pijakan dalam melakukan aktivitas. Budaya non-material tersebut dalam bentuk nilai-nilai, norma, gagasan yang selalu diikuti dengan penuh kesadaran bahkan kepatuhan. Dengan kata lain, nilai-nilai merupakan sesuatu yang abstrak tentang tujuan budaya yang dibangun bersama melalui simbol, bahasa, pesan-pesan verbal maupun non-verbal. Dengan demikian nilai-nilai membentuk sikap kita untuk membuat penilaian tentang benar dan salah, baik dan buruk, serta rukun dan tidak rukun.

Nilai-nilai kultural diyakini akan menjadi pedoman masyarakat Ternate yang multietnis dan multikultural, yang secara umum kelompok etnis yang asli mendiami Maluku sudah sangat heterogen, dan semua suku tersebut sebagian besar terkonsentrasi di Ternate sebagai ibukota provinsi yang secara laten berpotensi menimbulkan konflik horizontal sebagaimana yang terjadi pada tahun 1999-2001, yaitu sekitar 17 anak suku, diantaranya; Ternate, Tidore, Jailolo, Bacan, Sahu, Ibu, Loloda, Galela, Tobelo, Kayoa, Makian, Kao, Gane, Obi, Taliabu, dan Sanana, tingkat heterogenitas tersebut dilengkapi lagi dengan para migran yng datang dari berbagai pulau di nusantara, terdiri dari Suku Jawa, Bugis Makassar, Mandar, Padang, Aceh serta Buton. Dan sebagian suku membentuk segregasi tersendiri misalnya ditemukan kampung Makassar, kampung Melayu, kampung Cina, dan kampung Falajawa.

Dalam lingkup kebudayaan Maluku Utara popular istilah Moloku Kie Raha yang diklaim sebagai lembaga adat bersama antara empat kesultanan (Ternate, Tidore, Bacan, dan Jailolo), Sebagai pengejawantahan rasa untuk melanjutkan hidup dalam bentuk suatu gemeinshaf yang disusun oleh pikiran. Dalam pergaulan hidup tumbuh dan berkembang kegiatan yang mengkristal menjadi kebiasaan, karena dilakukan berulang-ulang dan ditransmisikan secara turun-temurun sehingga mengeras menjadi tradisi normatif dan adat-istiadat. Moloku Kie Raha adalah suatu pandangan dunia masyarakat Ternate, inti dari konsep Moloku Kie Raha adalah 
keseimbangan (equilibrium) yang bertolak dari falsafah Kie Raha, yaitu Jou se ngofangare yang diterjemahkan menjadi kau dan aku (dalam arti bahwa segala sesuatu yang ada dipermukaan bumi, segala pemikiran, tindakan yang akan ditempuh harus berdasarkan pada kehendak engkau dan kehendak aku). (Jaelan Usman, 345). Dengan demikian masing-masing kesultanan dapat mengatur dan mengurus dalam negerinya dengan tetap menjaga dan memelihara keseimbangan. Secara konsepsional, filisofi term Jou se ngofangare merupakan basis kehidupan dan peradaban moloku kie raha yang memposisikan semua manusia setara dihadapan Tuhan tanpa hegemoni dan subordinasi satu sama lain.

Secara ontologis (ilmu tentang proses sesuatu menjadi ada), maka Jou se ngofangare merupakan al-Awwal (salah satu nama Allah) yang bermakna asal segala sesuatu termasuk manusia. Jika sesuatu itu diadakan oleh al-Awwal, maka aksiomanya adalah bahwa alam dan seluruh isinya pasti berasal dari al-Awwal, yaitu Jou se ngofangare. Pada tahap ini sudah terjadi dialog awal antara engkau dan aku. Sehingga terjadilah ma'rifah. Peristiwa tersebut dideskripsikan dalam bahasa Ternate dalam bentuk puitis yang mengandung pengertian religius dan filosofis yang sangat kental yang dikenal dolo bololo, yaitu; gudu moju sito nonako, ri Jou sito suba (aku sudah mengenalNya, karena aku sudah menyembahNya), dan gudu moju sito suba, ri Jou sito nonako (aku menyembahNya karena aku mengenalNya).

Dalam sejarah pemikiran Moloku Kie Raha, filosofi Jou se ngofangare mengalami proses materialisasi sehingga mengkristal menjadi budayajika budaya dihipotesiskan sebagai konkretisasi dalam pikiran manusia yang masih berada pada tataran abstrak, maka filosofi Jou se ngofangare dibumikan dalam ruang dan waktu yang obyektif dan universal menurut klaim yang dikemukakan Mudzaffar Syah (2005) berbentuk gobehe dopolo romdihi (burung berkepala dua berbadan satu dan berhati satu).

Kemudian Islam masuk ke Ternate atau Kie Raha dan mengajarkan azas Islam, yaitu dua kalimat syahadat dalam bahasa Arab berbunyi Asyhadu an-Lailaha Ilia Allah wa asyhadu anna Muhammad Rasulullah, diasumsikan oleh kalangan masyarakat Ternate sesuai dengan prinsip Jou se ngofangare, yang jika diuraikan, maka klausul Asyhadu an La llaha Illah Allah adalah relevan dengan istilah Jou, sedangkan kalimat Wa asyhadu anna Muhammad Rasulullah sebangun dengan ngofangare. Lambang goheba yang berkepala ganda melambangkan Jou se ngofangare yang dalam persfektif Islam merupakan dua kalimat syahadat. Makna yang biasa ditafsir dari istilah gobeha dopolo adalah Ada yang mengadakan, sedangkan dalam pergaulan manusia diartikan sebagai pemimpin dengan rakyatnya, serta hubungan manusia dengan manusia yang semuanya harus bersatu hati. 
Falsafah Jou se ngofangare (aku dan kau) yang merupaka bagian dari titik tolok guna memasuki alam pikiran dari nilai-nilai abstrak adat Kie Raha.

Memahami makna budaya Jou se ngofangare bagi masyarakat sebagai dasar dan sumber spirit budaya lokal. Dengan kata lain sebagai sebuah representasi kebudayaan melalui pendekatan lokal untuk memahami makna proses syahadat yang intinya pengabdian kepada Tuhan yang menempatkan manusia pada posisi yang paling tinggi dan terhormat yang setara dan menyatu tapi tak bersinggungan, berpisah tak berjarak. Inilah replikasi budaya Maluku Utara dan Ternate khususnya, mereka sangat menghindari untuk mengkafirkan orang lain, curiga atau menyimpan perasaan dendam, sikap tersebut sekaligus menjauhkan diri dari meiakukan tindakan kekerasan. Mereka berasumsi bahwa bahwa kecurigaan dan mengkafirkan orang lain tidak akan terjadi di Ternate sebab masyarakat tersebut menempatkan Tuhan pada posisi yang paling tinggi. Tuhan bukanlah aktor dalam hidup kita, melainkan manusia sendirilah yang berperan sebagai aktor, sedangkan Tuhan berperan sebagai sutradara, problemnya jika Tuhan diposisikan sebagai aktor dalam domain kultur Ternate maka komunitas Ternate akan sangat mudah menyalahkan bahkan mengkafirkan orang yang tidak sependapat dengan mereka atas nama Tuhan, seperti kerusuhan yang berbasis SARA (suku, agama, ras, dan antar golongan) sebagaimana konflik yang terjadi di beberapa wilayah di Maluku dan Maluku Utara. (Gamaluddin A. Gafur, 2005: 42). Pendapat di atas dielaborasi (didukung) oleh Adam Ma'rus (2005) dengan menyatakan bahwa praktek keagamaan seseorang ataupun masyarakat selalu melahirkan bentuk-bentuk plural, bahkan melahirkan pengelompokan (segregasi). Oleh karena praktek keberagamaan bila dilihat secara sosiologis maka akan selalu mengemuka agama yang berwajah ganda. Suatu saat bias menjadi kekuatan integrasi, contoh kasus perjuangan penegakan kemerdekaan dengan menegakkan spirit keberagamaan. Disisi lain agama kadang "dipakai" sebagai kekuatan disintegrasi. Dengan demikian agama mampu menciptakan ikatan kohesi sosial dan pada waktu yang sama menciptakan pemisahan di antara kelompok yang awalnya solid, contoh kasus kerusuhan yang bernuansa agama di Maluku Utara. Wajah agama lanjut Ma'rus yang telah berbaur dengan simbol-simbol kultural secara laten memendam potensi konflik terutama masalah agama diseret kepada pertarungan kepentingan ekonomi dan politik dari para pemeluknya, yang membuat kesulitan dalam memisahkan antara agama dengan politik. Terdapat beberapa nilai lokal yang mendukung eksisnya Jou Se Ngofangare, yaitu terdiri dari;

\section{Adat Se Atorang}

Secara sederhana konsep adat dapat dimaknai sebagai perilaku atau perbuatan manusia yang sudah terpola yang dilakukan secara terus-menerus sehingga mengkristal menjadi kebiasaan, yang didalamnya mengandung nilai-nilai untuk

dijadikan basis pijakan dalam mengatur perilaku individu maupun kelompok 
La Sakka

masyarakat. Demikian pula halnya adat se atorang yang merupakan produk hukum yang sebelumnya berulang-ulang serta berkelanjutan dilakukan oleh masyarakat Ternate sebagai jaminan kepastian hukum adat guna terpeliharanya keseimbangan dan harmoni. Adat se atorang merupakan hukum Ilahi yang harus diterapkan manusia. Dan sudah menjadi ketetapan bahwa perilaku manusia dibatasi oleh sejumlah aturan agar terjadi keselarasan dan keseimbangan hubungan antara mereka. Dan secara teoritis biasa dikatakan bahwa apabila dalam suatu masyarakat tidak memiliki hukum yang mengaturnya maka yang muncul adalah kekacauan (chaos) dan anarkisme. Dalam kondisi masyarakat yang anomali serta anarkis, maka hukum yang berlaku adalah hukum rimba yang hanya mengandalkan kekuatan. Namun hukum juga harus memiliki basis pijakan dalam penerapannya, dan pijakan yang utama adalah ada pada nilai-nilai kemanusiaan (humanity). Di dalam implementasinya semua yang berkepentingan dengan hukum, baik pencari keadilan maupun eksekutor dan legislator wajib menjalankan dan melaksanakan sifat-sifat Ilahi yang ada dalam dirinya.(Hidayatullah M, Syah, 2006; 106-107).

Jika nilai-nilai kemanusiaan dan Ilahiyah yang menjadi pijakan suatu aturan hukum, maka bisa dikatakan bahwa hukum tersebut adalah hukum Ilahi. Jika sudah menyangkut dengan hukum Ilahi, maka tujuan hakiki dari hukum mestinya adalah menjaga harkat dan martabat serta akhlak dan moral manusia. Yang dimaksud dengan hukum Ilahi bukanlah hukum yang bersumber langsung dari Tuhan, melainkan hukum yang dibuat berdasarkan pada nilai-nilai kemanusiaan dengan betul-betul menjalankan sifat-sifat Ilahiyah yang melekat dalam diri manusia.

Demikianlah makna dari adat se atorang yang merupakan ilmu pengetahuan yang diberikan Allah kepada manusia guna menciptakan hukum agar dapat mengatur perilaku individu dengan individu, bahkan dengan masyarakat dalam semua aspek kehidupannya. Inilah salah satu nilai lokal yang melatari terbentuknya lembaga kesultanan-kesultanan di Moloku Kie Raha khususnya kesultanan Ternate yang berkaitan dengan hukum Sangaji dan hukum sao sio, dan pemimpinnya digelari dengan jo hukum (jo berasal dari kata Jou yaitu Tuhan).

\section{Adat Se Kabasaran}

Manusia adalah makhluk yang sangat tinggi tingkat ketergantungannya khususnya kepada sesamanya manusia, sebagaimana diistilahkan oleh Aristoteles bahwa manusia adalah zoonpoliticon. Kesalingtergantungan inilah yang mendasari manusia untuk acapkali mengelompok serta membentuk segregasi sosial. Dalam rangka mengatur soliditas maka dibentuklah lembaga yang berfungsi mengelola dan mengatur kebutuhan hidup manusia. Terbentuknya lembaga dengan struktur dan fungsi manajemennya melahirkan sejumlah otoritas dan power (kekuasaan) sebagai pengejawantahan organisasi sosial tersebut. 
Organisasi sosial berkembang mengikuti dinamika perubahan yang dialami masyarakat yang membentuk pranata tersebut, jika sebelumnya sistem manajemennya sangat sederhana sesuai pola hidup serta perilaku masyarakatnya yang masih pada pola hidup primitif, maka seiring dengan pesatnya kemajuan manusia berimplikasi pada semakin kompleks dan complicated pengeMam pranata sosial. Disisi lain manusia adalah makhluk yang di anugerahi amanat sebagai khalifah di bumi, yang merupakan keniscayaan untuk melengkapi dirinya agar optimal dalam menjalankan tugas sebagai pemimpin. Pada prinsipnya kekuasaan yang ada pada manusia adalah otoritas dari lembaga yang dipimpinnya, sehingga kekuasaan dijalankannya dibatasi oleh sejumlah etika politik dan hukum yang secara ijma' disepakati, namun karena kecenderungan manusia ingin memonopoli bahkan mengharapkan absolusitas dalam memimpin maka yang terjadi kemudian adalah penyalahgunaan wewenang dengan cara memaksakan kehendaknya kepada rakyat yang dipimpinnya.

Adapun kekuasaan Tuhan adalah kekuasaan yang dijalankan untuk dan atas nama Tuhan semata dalam rangka ibadah suba Jou dengan kesadaran diri bahvva kekuasaan adalah amanah bagi kepentingan manusia secara keseluruhan, bukan untuk kepentingan individu atau kelompok semata. Jika kesadaran ini telah mengkristal dalam diri manusia, maka tujuan diamanahkannya kekhalifahan kepada manusia akan menciptakan kerukunan, kesejahteraan, keselamatan, kebahagiaan dan keseiarasan dalam hidup manusiadi dunia maupun di akhirat. Oleh karena itu, harus disadari bahvva kekuasaan adalah suatu keharusan untuk mencapai kepastian hukum dalam menggapai tujuan hidup bersama yang aman dan rukun. Contoh dari kekuasaan Tuhan yang dijalankan manusia berdasarkan filosofi Jou se ngofangare adalah kekuasaan para kolano di Moloku Kie Raha, yaitu kolano dan bala samasama berada di puncak tertinggi, keduanya tidak mensubordinasi satu sama lain yang membedakannya hanya fungsi keduanya. Bala bertugas memberikan kemuliaan, kehormatan segenap jiwa raganya kepada kolano serta patuh kepada id'in (perintah) kolano, dan kompensasinya adalah kolano mengurusi bala dengan tulus melebihi kepentingan pribadi dan kelompoknya. Relasi kuasa antara bala dan kolano disimbolkan dengan nasi kuning dengan telur yang disebut dada dan suara rakyat adalah suara Tuhan, maka kekuasaan kolano adalah kekuasaan Tuhan. Sharing kekuasaan ini akan menjauhkan penumpukan kekuasaan dan kekayaan pada segelintirkecil orang sehingga relatif steril dari kontlik sosial.

\section{Galib Se Lakudi}

Galib se lakudi adalah ketetapan dan ketentuan Allah yang barlaku bagi manusia di semua aspek kehidupan, posisi manusia tidak memiliki kewenangan dan kemampuan untuk merubahnya. Dan kebebasan sesungguhnya milik Tuhan, dan karena kehendakNya manusia mampu menjalankan kebebasan relatif yang 
diberikan Tuhan, yang dikehendaki Tuhan terhadap manusis adalah tanggung jawab dari pelaksanaan kebebasan dari perbuatan dan perilakunya tersebut, demikian pula tanggung jawab secara horizontal kepada manusia dan alam semesta.

Galib se lakudi menjangkau seluruh sendi kehidupan manusia sebagaimana dikemukakan di atas, nilai lokal ini mengalami asimilasi dengan ajaran agama, baik Islam maupun Kristen, seperti salat, puasa, haji, kebaktian di gereja pada hari Sabtu dan Minggu, manusia menikah dengan tujuan mendapatkan keturunan juga bagian dari galib se lakudi, beipakaian dengan tujuan menutup aurat adalah galib se lakudi, dan lain sebagainya.

Prinsipnya, apabila perbuatan atau perilaku manusia melebihi atau melampaui ketetapan serta ketentuan (qadha dan qadhar) Ilahi, maka yang turun adalah ancaman dan sangsi. Mulai dari sangsi moral sampai hukuman fisik terutama hukuman yang sifatnya eskatologis (dihari kemudian).

\section{Sere Se Duniru}

Sere se duniru adalah tatacara dan aturan main yang ditetapkan Tuhan untuk dipatuhi semua manusia dan diwajibkan untuk diimplementasikan dalam membangun interaksi dan hubungan sosial, sebab jika manusia menyimpang dari tata cara dan aturan Ilahi, maka akan menciptakan disharmoni dan ketegangan bahkan konflik sosial, salat misalnya memiliki tata cara dan aturan yang secara konsisten dilaksanakan, begitu pula ibadah ritual dalam Kristen, Hindu, Budha, Yahudi dan lain-lain. Contoh yang paling kongkrit dari tata cara dan aturan yang sering keluar dari sistem Ilahi atau sere se duniru adalah perilaku politik pada tataran politk praktis, para politisi sering konflik memperebutkan kekuasaan politik. Dalam dunia politik manusia tidak lagi dipandang sebagai hamba Allah yang hams dilindungi harkat dan martabatnya, tetapi sebaliknya rival politik diasumsikan sebagai lawan yang hams di singkirkan. (Hidyatullah, 2006; 115)

Dalam dunia politik, lanjut Hidayatullah nilai-nilai kemanusiaan dan sifat-sifat Ilahiyah terpinggirkan, sebab doktrin politik adalah tidak ada kawan yang abadi, justru yang abadi adalah kepentingan politik. Ketika kepentingannya tidak sejalan, maka kawan akan menjadi lawan yang hams disingkirkan dengan segala macam cara, berawal dari pembunuhan karakter (character assassination) sampai kontak fisik. Akhirnya larangan Tuhan agar manusia menjauhi sifat-sifat munafik terabaikan begitu saja. \{Ibid, 116).

\section{Cing Se Cingare}

Secara harfiah cing se cingare berarti berbuat sesuatu agar perbuatannya itu dapat dilihat dan diperhatikan oleh orang lain. Suatu perbuatan jika dilakukan dan bersentuhan dengan suatu masalah ,maka akan mengundang orang untuk melihat dan memperhatikannya. Reaksi yang timbul dari aksi tersebut akan berbentuk

pengawasan dari berbagai pihak. Namun dalam konteks Suba Jou, pengertian itu 
tentu dirasakan terlalu sempit. Karena itu, makna yang terkandung di dalam kata dilihat atau diperhatikan bisa disinonimkan dengan diawasi atau pengawasan.

Jika kehidupan di bumi dipandang sebagai arketipe, maka pengawasan yang dilakukan pimpinan terhadap bawahannya bisa dianalogikan dengan pengawasan yang dilakukan Tuhan terhadap gerak seluruh benda di langit dan di bumi dan apaapa yang ada di antara keduanya, serta semua hal yang dilakukan, dipikirkan serta dirasakan manusia. Semuanya tidak akan lepas dari pengetahuan serta pengawasan Tuhan. Dengan demikian secara luas makna cing se cingare adalah pengawasan Tuhan terhadap semua gerak dan aktivitas manusia, baik yang dilakukan secara nyata maupun yang dilakukan tersebut rahasia sifatnya.

\section{Bobaso Se Rasai}

Rasa adalah konsep yang digunakan masyarakat Ternate untuk menunjuk salah satu panca indera manusia untuk merasakan berbagai jenis rasa, meliputi rasa manis, pahit, asam, asin, gembira, sedih, dan sebagainya. Hal ini menandakan bahwa manusia wajib menjaga "rasanya" karena rasa itulah yang akan merasakan segala sesuatu yang bersifat kesenangan dan kesakitan dunia dan akhirat. Dan termasuk merasakan penderitaan orang lain yang berbeda agama, budaya, etnis, dan bahasa.

Orang Ternate menyebut rasa dan merasakan tersebut dengan istilah bobaso se rasai, yang dalam dolo bololo diibaratkan "Lemo-lemo sio, lemo se marau, demo sagala demo, demo rimoi bato, jaga mada afa mara susah, tagal demo dadi kasangsard\exuk-')tmk, jeruk dengan daunnya, kata demi kata, berkatalah satu saja, jagalah mulut jangan sampai susah, karena kata akan jadi sengsara). Kearifan lokal tersebut memperingatkan manusia bahwa di dalam pergaulan hidup hendaknya manusia senantiasa menjaga kata-katanya, karena mulut (kata) bisa mendatangkan bencana. Orang-orang tua di Ternate menyimbolkannya dengan pohonjeruk, buah dan daunnya, seperti salah satu jenis jeruk yang memiliki duri dan sakit ketika tertusuk durinya, rasa buahnya asam, dan air yang keluar dari kulitnya mengandung butiran air yang membuat mata perih.

Bob aso se rasai adalah salah satu pengetahuan yang dianugerahkan Tuhan agar manusia dapat saling membina hubungan sosial dengan rukun dan harmonis, saling menjaga kehormatan diri, dan saling menjaga perasaan masing-masing. Dengan bobaso se rasai maka manusia terhindar dari tindakan menyalahkan orang lain.

\section{Car a Se Ngale}

Cara se ngale merupakan jalan Ilahi yang harus ditempuh manusia di dunia. yaitu perintah yang harus ditaati dan larangan yang harus dijauhi. Jika diandaikan Cara se ngale adalah ibarat ilmu dengan metodologinya, semakin tepat metode yang 
digunakan untuk mengkaji dan menganalisa suatu masalah, maka akan semakin tepat hasil yang diperoleh. Namun sebaliknya metode yang digunakan keliru maka muaranyapun akan keliru.

\section{Loa Se Bannar}

Perbuatan yang lurus dan benar itu adalah perbuatan Allah SWT sebagaimana yang dicontohkan oleh para Nabi dan RasulNya, yaitu perbuatan yang diridhai oleh Tuhan Yang Maha Pengasih dan Penyayang. Jika manusia di dalam memenuhi kebutuhannya selalu menempuh jalan yang lurus dan benar. maka hasil yang akan diperoleh adalah kebaikan. Semakin lurus dan benarjalan yang ditempuh, semakin baik hasilnya yang akan diraih.

Di dalam ilmu pengetahuan yang telah diberikan oleh Allah kepada manusia agar manusia memperoleh keselamatan hidup dunia dan akhirat, dalam bahasa Ternate disebut loa se bannar, yaitu kebenaran Ilahi yang ada pada manusia. loa se bannar adalah perbuatan yang lurus dan benar guna mencapai kebaikan yang telah ditunjukkan Tuhan kepada manusia melalui sikap dan perilaku para Nabi dan Rasul. Kita memang tidak bisa menjadi Nabi dan Rasul, tapi kita bisa dan harus meniru sikap dan perilaku Nabi dan Rasul untuk dijadikan suri tauladan bagi umat manusia masa kini. Karena sikap dan perilaku Nabi dan Rasul itu adalah sikap dan perilaku dari makhluk yang dikatakan manusia sempurna (insan kamil).

\section{Duka Se Cinta}

Manusia hidup telah ditakdirkan saling tergantung satu sama lain. Sehingga di dalam hubungan yang saling tegantung itu akan lahir sikap toleransi di dalam kehidupan, manusia akan turut merasakan apa-apa yang dirasakan oleh orang lain. Penderitaan yang dialami orang lain akan melahirkan sikap peduli terhadap derita yang dialami orang tersebut. Ini terbukti dengan kehadiran orang-orang, baik dalam rangka mengucapkan rasa belasungkawa maupun ikut serta menyumbangkan materi maupun suppor lainnya.

Jika kita kembali kepada awal kejadian manusia, maka manusia akan menyadari penyebab ketidakmungkinan manusia untuk tidak peduli kepada sesamanya ketika di antara mereka ditimpa musibah. Ini semua karena manusia diciptakan serta dibekah oleh Allah dengan sifat-sifat-Nya Yang Maha Pengasih dan Maha Penyayang, sifat Tuhan tersebut menjadi dasar dan landasan diciptakannya dunia beserta isinya. Oleh karena itu manusia akan senantiasa simpati terhadap penderataan dan peduli terhadap orang-orang disekitamya karena adanya nilai-nilai kasih sayang dan sifat-sifat Ilahiyah dalam dirinya. Dari sifat inilah lahir sikap saling menghormati, menghargai. rukun. dan toleransi terhadap orang yang berbeda keyakinan. Dalam dolo bololo dinyatakan 
tentu dirasakan terlalu sempit. Karena itu, makna yang terkandung di dalam kata dilihat atau diperhatikan bisa disinonimkan dengan diawasi atau pengawasan.

Jika kehidupan di bumi dipandang sebagai arketipe, maka pengawasan yang dilakukan pimpinan terhadap bawahannya bisa dianalogikan dengan pengawasan yang dilakukan Tuhan terhadap gerak seluruh benda di langit dan di bumi dan apaapa yang ada di antara keduanya, serta semua hal yang dilakukan, dipikirkan serta dirasakan manusia. Semuanya tidak akan lepas dari pengetahuan serta pengawasan Tuhan. Dengan demikian secara luas makna cing se cingare adalah pengawasan Tuhan terhadap semua gerak dan aktivitas manusia, baik yang dilakukan secara nyata maupun yang dilakukan tersebut rahasia sifatnya.

\section{Bobaso Se Rasai}

Rasa adalah konsep yang digunakan masyarakat Ternate untuk menunjuk salah satu panca indera manusia untuk merasakan berbagai jenis rasa, meliputi rasa manis, pahit, asam, asin, gembira, sedih, dan sebagainya. Hal ini menandakan bahwa manusia wajib menjaga "rasanya" karena rasa itulah yang akan merasakan segala sesuatu yang bersifat kesenangan dan kesakitan dunia dan akhirat. Dan termasuk merasakan penderitaan orang lain yang berbeda agama, budaya, etnis, dan bahasa.

Orang Ternate menyebut rasa dan merasakan tersebut dengan istilah bobaso se rasai, yang dalam dolo bololo diibaratkan "Lemo-lemo sio, lemo se marau, demo sagala demo, demo rimoi bato, jaga mada afa mara susah, tagal demo dadi kasangsara"(Jeruk-jeivk, jeruk dengan daunnya, kata demi kata, berkatalah satu saja, jagalah mulut jangan sampai susah, karena kata akan jadi sengsara). Kearifan lokal tersebut memperingatkan manusia bahwa di dalam pergaulan hidup hendaknya manusia senantiasa menjaga kata-katanya, karena mulut (kata) bisa mendatangkan bencana. Orang-orang tua di Ternate menyimbolkannya dengan pohon jeruk, buah dan daunnya, seperti salah satu jenis jeruk yang memiliki duri dan sakit ketika tertusuk durinya, rasa buahnya asam, dan air yang keluar dari kulitnya mengandung butiran air yang membuat mata perih.

Bob aso se rasai adalah salah satu pengetahuan yang dianugerahkan Tuhan agar manusia dapat saling membina hubungan sosial dengan rukun dan harmonis, saling menjaga kehormatan diri, dan saling menjaga perasaan masing-masing. Dengan bobaso se rasai maka manusia terhindar dari tindakan menyalahkan orang lain.

\section{Cara Se Ngale}

Cara se ngale merupakan jalan Ilahi yang hams ditempuh manusia di dunia. yaitu perintah yang hams ditaati dan larangan yang harus dijauhi. Jika diandaikan Cara se ngale adalah ibarat ilmu dengan metodologinya, semakin tepat metode yang 
digunakan untuk mengkaji dan menganalisa suatu masalah, maka akan semakin tepat hasil yang diperoleh. Namun sebaliknya metode yang digunakan keliru maka muaranyapun akan keliru.

\section{Loa Se Bannar}

Perbuatan yang lurus dan benar itu adalah perbuatan Allah SWT sebagaimana yang dicontohkan oleh para Nabi dan RasulNya, yaitu perbuatan yang diridhai oleh Tuhan Yang Maha Pengasih dan Penyayang. Jika manusia di dalam memenuhi kebutuhannya selalu menempuh jalan yang lurus dan benar, maka hasil yang akan diperoleh adalah kebaikan. Semakin lurus dan benarjalan yang ditempuh, semakin baik hasilnya yang akan diraih.

Di dalam ilmu pengetahuan yang telah diberikan oleh Allah kepada manusia agar manusia memperoleh keselamatan hidup dunia dan akhirat, dalam bahasa Ternate disebut loa se bannar, yaitu kebenaran Ilahi yang ada pada manusia. loa se bannar adalah perbuatan yang lurus dan benar guna mencapai kebaikan yang telah ditunjukkan Tuhan kepada manusia melalui sikap dan perilaku para Nabi dan Rasul. Kita memang tidak bisa menjadi Nabi dan Rasul, tapi kita bisa dan harus meniru sikap dan perilaku Nabi dan Rasul untuk dijadikan suri tauladan bagi umat manusia masa kini. Karena sikap dan perilaku Nabi dan Rasul itu adalah sikap dan perilaku dari makhluk yang dikatakan manusia sempurna (insan kainil).

\section{Duka Se Cinta}

Manusia hidup telah ditakdirkan saling tergantung satu sama lain. Sehingga di dalam hubungan yang saling tegantung itu akan lahir sikap toleransi di dalam kehidupan, manusia akan turut merasakan apa-apa yang dirasakan oleh orang lain. Penderitaan yang dialami orang lain akan melahirkan sikap peduli terhadap derita yang dialami orang tersebut. Ini terbukti dengan kehadiran orang-orang, baik dalam rangka mengucapkan rasa belasungkawa maupun ikut serta menyumbangkan mated maupun suppor lainnya.

Jika kita kembali kepada awal kejadian manusia, maka manusia akan menyadari penyebab ketidakmungkinan manusia untuk tidak peduli kepada sesamanya ketika di antara mereka ditimpa musibah. Ini semua karena manusia diciptakan serta dibekah oleh Allah dengan Sifat-sifat-Nya Yang Maha Pengasih dan Maha Penyayang, sifat Tuhan tersebut menjadi dasardan landasan diciptakannya dunia beserta isinya. Oleh karena itu manusia akan senantiasa simpati terhadap penderataan dan peduli terhadap orang-orang disekitamya karena adanya nilai-nilai kasih sayang dan sifat-sifat Ilahiyah dalam dirinya. Dari sifat inilah lahir sikap saling menghormati, menghargai, rukun, dan toleransi terhadap orang yang berbeda keyakinan. Dalam dolo bololo dinyatakan 
"Ittojb makatinyinga doka gosora se bualawa, om doro yo mamote,fo magogoru se madudara "(marilah kita bertimbang rasa bagaikan pala dan fulinya, masak bersama gugurpun bersama yang dilandasi rasa kasih sayang).

Dolo bololo di atas mengingatkan manusia untuk senantiasa memelihara sifat yang paling utama didalam membangun dan membina kehidupan yang rukun sebagai makhluk yang hidup berkelompok dan saling tergantung satu sama lain, yaitu sifat pengasih dan penyayang yang tertanam dalam diri manusia yang merupakan sifat Pengasih dan Penyayang dari Allah.

\section{Baso Se Hormat}

Kebiasaan orang Ternate di dalam pergaulan hidup sehari-hari adalah mengawali dengan mengucapkan nama Tuhan, yaitu Jou, misalnya "suba Jou ngon tagi kasa ge", dan akan dibalas dengan Jou suba, fangare/fajaru sari tagi, atau ketika orang mempersilakan tamunya duduk dengan kalimat "tego Jou", akan dibalas dengan " $n$ 'jo, Jou. Ada beberapa makna yang terdapat dalam kebiasaan-kebiasaan di atas, diantaranya: (1) sebagai pengakuan terhadap Tuhan yang ada dalam diri manusia, yang kemudian memunculkan penghormatan dan pengagungan serta penyembahan kepada Tuhan, (2) sebagai ungkapan rasa hormat terhadap sesama manusia. Kesimpulannya bahwa jika manusia telah memuliakan Tuhan, maka akan lahir sikap hormat-menghormati orang lain sebagai hamba dan ciptaan Tuhan. Ekspresi yang berbentuk sapaan yang memuat makna penghormatan terhadap sesama manusia dinamakan dengan baso se Iwnnat, yang dimaksudkan untuk terbangunnya keharmonisan dan kerukunan dalam pergaulan dengan orang yang kebetulan berbeda agama.

Apabila interaksi sosial dibangun berdasarkan sikap saling menghargai dipastikan akan tercipta keharmonisan dan kerukunan, sebagai implementasi dari diciptakannya manusia berbangsa-bangsa agar saling mengenal agar secara bersama-sama membangun harkat dan martabat manusia yang beragama. Membangun harkat dan martabat manusia secara bersama-sama berarti menjalankan nilai-nilai kemanusiaan dan nilai Ilahiyah. Dan manusia hanya bisa membangun harkat dan martabat secara bersama-sama apabila kerukunan dan keharmonisan dapat terwujud di dalam diri semua orang. Sebagaimana tergambarkan dalam dolo bololo, yaitufWgone doka dai loko, ahu yo mafara-fara, rubu-rubu yo ma moi-moi doka saya raku moi"(kita bagaikan kumbang di padang rumput, tumbuh hidup terpencar, namun terhimpun dalam satu genggaman, bagaikan hiasan serangkai kembang), terlihat bahwa konsep "ngone doka dai loko adalah manusia dengan berbagai bangsa, etnis, bahsa, ras, agama, dan budaya, ahu yo mafara-fara adalah kehidupan manusia yang secara geografis terpisah, ruburubu yo ma moi-moi dimaknai bahwa manusia hanya berbeda secara lahiriyah saja, sementara secara hakiki sama saja, yaitu sama-sama memilki nilai-nilai kemanusiaan 


\section{La Sakka}

dan sifat-sifat ketuhanan yang universal karena berasal dari diri yang satu. Ibaratnya kembang di atas yang memiliki warna yang beraneka ragamjika disatukan dalam satu ikatan, maka akan terlihat sangat indah. Demikian pula manusia yang berbeda-beda akan menjadi indah apabila hidup menyatu dalam kerukunan dan keharmonisan, inilah yang dikandung kalimata' doka saya raku moi' bagaikan hiasan kumpulan kembang.

\section{Bari (Gotong-royong)}

Gotong royong dalam bahasa Ternate disebut "bari", yang secara harfiyah dimaknai sebagai suatu kegiatan yang dilakukan dengan kesadaran sendiri tanpa ada paksaan dari pihak lain serta melibatkan banyak orang dan pekerjaan tersebut dilakukan bersama-sama tanpa mengharapkan upah atau gaji. Dengan demikian gotong royong yang dilakukan masyarakat Maluku Utara, khususnya di Ternate adalah gotong royong yang didasarkan pada keikhlasan manusia membantu manusia lainnya. Dan ini merupakan implementasi dari falsafah "co'oukaha, kie se kolano", dengan suatu keyakinan bahwa pada hakekatnya mendorong manusia dengan ikhlas sama halnya dengan menolong diri sendiri (hubungan antara manusia dengan manusia).

Maksud dengan menolong diri sendiri lebih mengarah pada pemahaman religius bahwa setiap perbuatan manusia pasti mendapat ganjaran dari Tuhan Yang Maha Pengasih lagi Penyayang, perbuatan baik pasti mendapatkan pahala. Begitu pula sebaliknya (hubungan antara Tuhan dengan manusia) hanya kadar keikhlasanlah yang menjadi perhitungan Tuhan dalam menilai setiap perbuatan hambanya. Jadi bari dalam konsep budaya Ternate adalah suatu kegiatan kemanusiaan yang didasarkan pada keikhlasan sebagai pengakuan diri (co'ou) dengan tidak mengharapkan imbalan materi sebagai wujud dari kesamaan asal (kaha) yang merupakan kehendak kekuasaan (kie) yang sudah ada dalam diri manusia sebagai makhluk yang paling sempurna. Budaya bari yang masih orisinil saat ini, ditemukan dibeberapa kelurahan, diantaranya, di Kelurahan Taduma, Kelurahan Aftador, dan Kelurahan Doropedu, Kecamatan Pulau Ternate, penerapan nilai budaya bari yang masih aktual, dapat dilihat pada saat awal krisis moneter, para masyarakat Taduma melakukan aktivitas gotong royong dalam membangun rumah kediaman penduduk sebanyak 35 buah semi permanen dan permanen termasuk rumah ibadah, rumah guru yang seluruhnya dibangun atas prakarsa dan swadaya masyarakat. Begitu pula pembangunan rumah adat (fala soa) di Pantai Ave Kelurahan Aftador.

Nilai lokal bari telah berkembang di Kelurahan Taduma sejak tahun 1800-an yang diprakarsai oleh para leluhur masyarakat Taduma dan digunakan secara efektif dalam melawan Belanda dan Jepang pada masa perjuangan. Bagi masyarakat Ternate, dan masyarakat Taduma khususnya, setiap pelaksanaan kegiatan pembangunan 
apa saja dalam rangka menyejahterakan orang lain, maka sangat mudah memobilisasi melalui sarana budaya bari yang telah mendarahdaging dalam kehidupan masyarakat Ternate.

\section{B. Fungsi Dan Manfaat Terhadap Kerukunan}

Beberapa budayawan mengemukakan bahwa resolusi konflik dengan mengacu kepada nilai-nilai lokal sebagaimana dikemukakan di atas selama ini telah terbukti mampu mempersatukan semua komponen masyarakat yang berbeda latar belakang, baik perbedaan agama, etnis, dan budaya yang selama beabad-abad telah mendiami wilayah Maluku, walaupun diakui bahwa sejarah keempat kesultanan di Maluku Utara atau popular secara kultural sebagai Moloku Kie Raha dalam perkembangannya acapkali diwarnai sengketa dan konflik, terutama konflik antara Ternate dan Tidore.

Kalaupun belakangan ini muncul lagi konflik internal pada tahun 1999 sampai tahun 2001 yang merupakan pertarungan kepentingan elit-elit politik lokal dalam memperebutkan posisi serta sumber daya strategis setelah terbentuknya Provinsi Maluku Utara. Menarik hikmah dari peristiwa kelam tersebut, pemerhati budaya dengan dukungan masyarakat berupaya kembali menggali dan menelusuri nilai-nilai lokal setempat. Sebagaimana dikemukakan oleh salah seorang informan AP (57 Th) bahwa.;" Konflik pada dasarnya merupakan suatu fenomena yang alamiah dan pasti ada dan mengada di semua pola hubungan dan juga budaya. Perkembangan dan kemajuan suatu konflik tidak lepas dari makna dan interpretasi yang diletakkan komunitas setempat pada perilaku peristiwa tertentu, sehingga ia sangat spesifik kultural. Dengan demikian, dapat dengan mudah dipahami bahwasanya suatu konflik tumbuh melalui suatu proses interaktifyang didasarkan pada pencarian dan penciptaan.

Mencermati pandangan di atas, tidak berlebihan jika dikatakan bahwa untuk memahami, menyelesaikan suatu konflik sekaligus membangun harmoni. Maka kepekaan akan nilai-nilai lokal yang mengkristal dalam komunitas seperti di Kota Ternate yang sebagian komponennya telah mengalami erosi yang awalnya sangat mengedepankan kerukunan, harmoni, dan kebersamaan. Pentingnya nilai-nilai lokal dalam membangun kerukunan dijelaskan secara gamlang oleh Jaelan Usman (38 Th).

"Kita hams mengedepankan kembali nilai-nilai budaya tradisional dan diperlukan penelitian serta penelusuran yang lebih komprehensif mengenai mekanisme penyelesaian konflik dan upaya membangun kerukunan yang selama ini dikenal masyarakat Maluku Utara dari berbagai etnis dan agama yang berintraksi didalamnya. Perbedaan nilai norma tentu saja akan dijumpai karena hukum adat yang berbeda, akan tetapi logikanya akan sama. Karena itu perlu diciptakan pendekatan yang sangat hati-hati dengan memperhatikan praktek-praktek yang diwarnai dengan 
budaya masing-masing. Disinilah perht digunakan hukum adatyang memberikan mekanisme bagipihak yang bersengketa".

\section{Sistem Pelestarian}

Kita ketahui bahwa setiap manusia sebagai pribadi maupun sebagai masyarakat mempunyai falsafah dalam memandang alam dan dunianya, serta kehadirannya dalam alam ini. Titik tolok pemikiran sebagai sumber pengetahuan yang telah membudaya tersebut adalah Jou se ngofangare. Falsafah ini telah melahirkan tata nilai dan adat yang terpelihara dan dipraktekkan secara terus-menerus sehingga menjadilah ajaran normatif secara kultural bahkan telah berubah menjadi hukum adat.

Menurut Margarito Kamis (Dalam Mudzaffar, 2005: 201), bahwa terminologi Juo se ngofangare yang berfungsi sebagai basis nilai transformatif yang secara harfiah bermakna Tuhan dan aku; Tuhan sebagai pencipta sedangkan manusia sebagai ciptaanNya atau Jou menunjuk kepada Tuhan dan ngare menunjuk kepada manusia, individu atau kumpulan individu yang membentuk sebuah komunitas, konsep ini paralel dengan konsep tauhid. Konsep tersebut dengan sendirinya menunjuk pada Allah swt dan hamba (ciptaannya), walaupun manusia beiposisi sebagai hamba, Allah tidak lantas mengekang hambaNya, dalam konteks ini terdapat sebuah persfektif yang luar biasa, yakni kesejajaran, kesamaan derajat di antara ciptaanNya. Dan Nabi Muhammad saw sebagai tokoh besar, yang kebesaran dan popularitasnya, yang telah berhasil secara sungguh-sungguh mengangkat martabat manusia.

Mengingat fenomena kerusuhan dan konflik yang memerosotkan nilai-nilai kemanusiaan, maka muncul upaya-upaya untuk kembali melakukakan rekonstruksi (penelusuran kembali) dalam rangka melesrarikan nilai-nilai lokal seperti Jou se ngofangare, bukan hanya di Ternate, lanjut Margaritho, tetapi juga diseluruh Indonesia yang kini ditandai adanya kerinduan untuk kembali pada masa lalu yang memiliki kearifan sebagai jalan keluar dari situasi yang memerosotkan mutu kemanusiaan. Diperlukan suatu kerjasama strategis, cerdas, jujur dengan semangat kebersamaan yang utuh untuk tidak hanya memikirkan pemecahannya tetapi upaya konkrit untuk tetap diterapkan dalam kehidupan sehari-hari. Strategi jitu menurut Sukardi dan Basir Awal, yang harus dibangun akibat gejala-gejala ketercerabutan budaya dan ketertinggalan budaya dalam era globalisasi adalah mengarahkan kepada revitalisasi (pembangunan kembali) nilai-nilai budaya Moloku Kie Raha khususnya Jou se ngofangare di Kota Ternate untuk memperkuatjati diri budaya serta identitas nasional, serta menjadikan nilai-nilai lokal sebagai tali yang memperkuat solidaritas dan kerukunan. Dalam konteks ini, menurut Gufran Ibrahim (2005;xvi) upaya penelusuran, penggalian dan penafsiran ulang serta penguatan nilai-nilai budaya lokal 
menjadi penting, sebab akan memperetegas komitmen kultural bagi penyelamatan akar kearifan budaya setempat dari gempuran budaya asing (global), kesadaran kultural ini dapat menjadi pemandu masa depan, dan merupakan cara yang efektif dalam kerangka pelembagaan dan pembelajaran budaya lokal.

Sebagai simbolisasi kultural adat se atorang dan seterusnya merupakan pintu landasan terbentuknya kohesi dan ikatan sosial menuju masyarakat madani, karena masyarakat madani mengandung syarat keadilan, kemajemukan, kerukunan, partisipasi, penghargaan atas hak asazi dan martabat manusia, rasional, serta etis. Solusi kultural yang ditawarkan oleh nilai lokal di atas sebagai pintu masuk untuk memenangkan semua pihak.

\section{KESIMPULAN DAN SARAN}

\section{A. Kesimpulan}

Kota Ternate dengan latar belakang wilayah yang terdiri dari pulau-pulau bergunung vulkanis yang sebagian masih aktif, dan penduduknya tergolong religius dan heterogen, baik pada aspek agama, etnis, budaya, dan bahasa, bercirikan dengan keberadaan agamaagama yang diakui Negara. Demikian pula keanekaragaman budaya dan suku bangsa (multikultural).

Masyarakat Ternate selama ini dikenal sangat religius dan konsisten memelihara nilai-nilai budaya mereka, keterikatan kepada budaya sangat nampak pada nilai-nilai lokal yang telah mengalami proses akulturasi dengan ajaran Islam, diantaranya sangat menonjol pada pelaksanaan upacara-upacara termasuk siklus hidup yang sebelumnya sarat dengan nuansa animisme dan dinamisme, sepeiti upacara adat kelahiran, memotong rambut, meminang, pemikahan hingga upacara kematian yang kini sangat kaya dengan ajaranajaran sufistik Islam, demikian pula yang nampak pada nilai lokal utama di Kota Ternate, yaitu: Jou Se Ngofangare yang memuat beberapa prinsip, meliputi; (1) Adat se atorang (hukum yang mengatur perilaku indi vidu dalam melakukan interaksi sosial), (2) Galib se lakudi (pembagian kekuasaan secara adil), (3) Sere se duniru (tata cara yang ditetapkan Tuhan), (4) Cing se cingare (pengawasan Tuhan), (5) Bobaso se rasai (merasakan atau peduli pada penderitaan orang lain), (6) Cara se ngale (jalan Ilahi yang hams ditempuh), (7) Loa se banar (petbuatan yang benar), (8) bari (gotong royong) nilai yang menempatkan manusia pada posisi terhormat dan bermartabat sebagaimana penghargaan Tuhan kepada mereka, hal ini dapat dicapai jika manusia secara konsisten mematuhi aturan dan mendekatkan diri serta menjadikan Tuhan sebagai pengawas atas semua aktivitas yang dilakukannya. Nilai utama tersebut akan mengantarkan manusia untuk saling menghargai, menghormati dan berkomitmen untuk hidup rukun dan harmonis. 
La Sakka

\section{B. Saran-saran}

1. Dalam upaya menemukan formula resolusi konflik yang tepat dan efektif sekaligus untuk menyelesaikan konflik yang selama ini menggelayuti bangsa, Pemerintah diharapkan untuk lebih proaktif menerapkan penyelesaian yang sifatnya button up dengan melibatkan partisipasi masyarakat serta nilai-nilai budaya yang masih terpelihara selama ini, dan telah terbukti mampu meredam potensi-potensi konflik dan menjaga kerukunan demikian pula kohesi sosial.

2. Diperlukan penelusuran dan inventarisasi lebih lanjut terhadap nilai-nilai lokal yang ditengarai masih banyak belum terungkap, sebab dikhawatirkan nilai-nilai lokal tersebut akan punah oleh perubahan zaman.

\section{DAFTAR PUSTAKA}

Abdurrahman, Jusuf. 2006. Nilai Dasar, wujud dan Dinamika Budaya Moloku Kie Raha. Ternate. Dinas Kebudayaan Dan Pariwisata. 2005. Mengungkap Catalan Budaya Moloku Kie Raha, dalam Mudzaffar Syah. Ternate. HPMT.

Bungin, Burhan. 2003. Analisis Data Penelitian Kualitatif. Get.I. Jakarta. PT. Raja Grafindo

Gafur, Gamaluddin. 2005. Memahami Kultur Maluku Utara dan Nilai Identitas Bangsa, dalam Mudzaffar Syah. HPMT. Ternate.

Hasbullah, Jousairi. 2006. Sosial Capital; Menuju Keunggulan Budaya Manusia Indonesia). Jakarta. MR-United Press.

Soelarto. tth. Sekelumit Monograf Daerah Ternate. Ditjen Depertemen Pendidikan Dan Kabudayaan RI.

Syah, Mudzaffar. 2005. Moloku Kie Raha Dalam Persfektif Budaya dan Sejarah Masuknya Islam. HPMT Press. Ternate.

Usman, Jaelan. 2006. Konflik dan Perubahan Sosial: Studi Sosiologis Politik di Maluku. Makassar. Pascasarjana Universitas Hasanuddin, 